\title{
Biological Solid-state NMR at ETH Zurich
}

\author{
Giorgia Zandomeneghi ${ }^{\mathrm{a}}$, Werner Maas ${ }^{\mathrm{b}}$, and Beat H. Meier ${ }^{\star a}$
}

\begin{abstract}
Solid-state Magnetic Resonance has been greatly developed over the past decade. Higher field spectrometers and other technical developments are expected to lead to further significant improvements.
\end{abstract}

Keywords: Amyloid fibrils · Fast MAS · High-field NMR · Membrane proteins · Sedimentation

\section{Solid-state Biological Applications at Present and in the Near Future}

Solid-state NMR has now developed to a point where a breakthrough in the field of structure determination for proteins is imminent. A number of high-resolution structures of uniformly or extensively ${ }^{13} \mathrm{C}$ , ${ }^{15} \mathrm{~N}$-enriched micro-crystalline proteins have been determined using solid-state NMR with a precision approaching that of liquid-state NMR or X-ray. ${ }^{[1-8]}$ Globular proteins can often be characterized by $\mathrm{X}$-ray crystallography and liquid-state NMR spectroscopy, but solid-state NMR adds additional und unique possibilities, e.g. in the context of dynamical investigations, ${ }^{[9,10]}$ or in the structural characterization of sedimented instead of crystallized proteins. ${ }^{[11,12]}$

Protein misfolding and subsequent aggregation is at the origin of over 20 human diseases termed 'conformational' diseases including Alzheimer's, Parkinson's and the prion diseases. The fundamental mechanism of the misfolding of polypeptides leading to their aggregation and associated diseases is far from being understood, partially because atomic-resolution structures are not available. In fact, prion fibrils are heterogeneous, high-molecular weight particles and, therefore, neither suitable for crystallography nor solution-state NMR studies. On the other side, amyloid fibrils represent an ideal target for solid-state NMR studies. ${ }^{[13,14]}$
In 2008 we determined the first atomic-resolution $3 \mathrm{D}$ structure of a prion in its amyloid form, namely HET-s(218-289), the prion forming domain of the fungal prion HET-s (Fig. 1). ${ }^{[15,16]}$ The resulting structure turned out to be more complex than expected from model peptides. ${ }^{[17]}$ In brief, HET-s(218-289) forms a left-handed $\beta$-solenoid, with each molecule forming two helical windings (Fig. 1). The core of the fibril is defined by three $\beta$-strands per winding (thus, six $\beta$-strands per molecule) that form in-register parallel $\beta$-sheets. A two-residue $\beta$ arc binds the $\beta$-strands $\beta 1 \mathrm{a}$ and $\beta 1 \mathrm{~b}$ (and $\beta 3 \mathrm{a}, \beta 3 \mathrm{~b}$ ) changing the inside-outside pattern of side chains and leading to an approximately rectangular kink in the strand at K229 and E265. The connection $\beta 1 b-\beta 2 a$ (and $\beta 3 b-\beta 4 a$ ) is provided by a three-residue $\beta$ arc, allowing for the orientation change of the polypeptide backbone by $\sim 150^{\circ}$. The high level of structural complexity and the stability of HET-s(218-289) are explained by the formation of the compact hydrophobic core, at least 23 hydrogen bonds per molecule, three salt-bridges and two asparagineladders. The structure gives a first glimpse into the world of amyloids and suggests that considerably structural complexity and diversity may be expected. It should be pointed out that the introduction in our lab of a $850 \mathrm{MHz}$ spectrometer has been a major factor in the success of this project. In fact, the spectral sensitivity and resolution obtained with the $850 \mathrm{MHz}$ spectrom- eter were significantly improved over the ones provided by our previously highest field spectrometer, namely a $600 \mathrm{MHz}$ instrument.

The knowledge of the structure of HET-s(218-289) in its amyloid form has now allowed us to characterize the pharmacophore of these amyloid fibrils. As a start, we have investigated the binding mode to the HET-s(218-289) fibrils of Congo red, one of the most common dyes used to detect amyloid fibrils in vitro and in vivo. ${ }^{[18]}$ By using unlabeled Congo red and uniformly ${ }^{13} \mathrm{C},{ }^{15} \mathrm{~N}$ labelled as well as deuterated HET-s(218-289) fibrils, and experiments based on chemical-shift mapping and on polarization transfer, we have found that Congo red binds to the fibrils highly site-specific by interacting with residues flanking a groove in the vicinity of a $\beta$-arc (Fig. 2). Remarkably, a single point mutation, designed according to the binding information, created an artificial amyloid structurally indistinguishable from the HET-s prion domain but non-stainable by Congo red. This unexpected binding selectivity supports the feasibility of designing selective anti-amyloidogenic drugs. ${ }^{[18]}$

HET-s is only a beginning and a convenient model system - although a very important model for a functional protein ${ }^{[19]}$ - on the way to the investigation of the biologically important full-length prions ${ }^{[20,21]}$ and towards determining the unknown structure of medically important amyloids, e.g. a-beta ${ }^{[13]}$ and $\alpha$-synuclein ${ }^{[22,23]}$

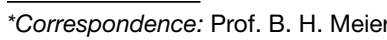
aPhysical Chemistry ETH Zurich

Wolfgang-Pauli-Strasse 10

$\mathrm{CH}-8093$ Zurich

Tel.: +4144632 4401

Fax: +4144632 1621

E-mail: beme@ethz.ch

bBruker Biospin

Industriestrasse 26,

$\mathrm{CH}-8117$ Fällanden
}

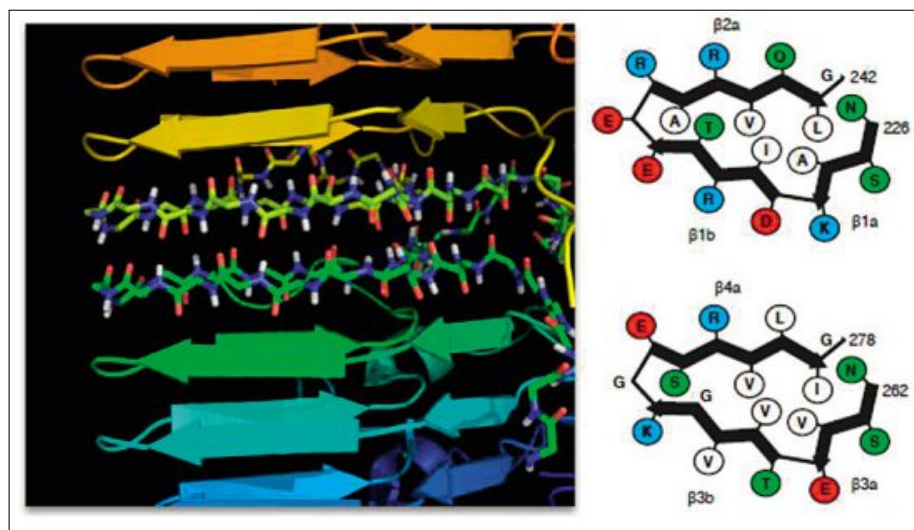

Fig. 1. Atomicresolution structure of HET-s(218-289) as determined from solid-state NMR data (PDB Accession Code: 2RNM). On the right panel a schematic representation of the core of the fibril formed by the two layers. Figure partially adapted from ref. [15]. 
involved respectively in Alzheimer's and Parkinson's diseases. In addition, it is an ideal test system for establishing studies addressing the water accessible sites, ${ }^{[24-26]}$ cross-seeding of homologue proteins, ${ }^{[27]}$ as well as the structure-infectivity relationship. ${ }^{28-30]}$

As mentioned above, the advent of higher magnetic fields was essential to the progress of the HET-s projects. In fact, the dispersion of the NMR signals is proportional to the magnetic field strength $\mathrm{B}_{0}$. The residual line broadening is mainly determined by spin-spin interactions ( $\mathrm{J}$ coupling as well as dipolar couplings) and is, therefore, largely independent of the external magnetic field. Thus, the separation of the individual lines increases with increasing magnetic fields. Our experience with the benefits of high magnetic fields is illustrated by Fig. 3, where the simulated spectra for the same sample at $\mathrm{B}_{0}=14.1$, 20.0 and $25.8 \mathrm{~T}$ (corresponding to a proton Larmor frequency of $600,850,1100$ $\mathrm{MHz}$, respectively) are compared. The left panel shows the increased resolution we gained going from 600 to $850 \mathrm{MHz}$, which allowed us to obtain the spectral assignment and the 3D structure of the protein in its fibrillar form. ${ }^{[15]}$ The right panel shows the line widths predicted for a spectrum at $1.1 \mathrm{GHz}$ compared with our experimental data at $850 \mathrm{MHz}$. The gain in resolution is evident.

Magnetic fields beyond $1 \mathrm{GHz}$ are expected to provide important new opportunities in structural biology and pharmaceutical applications, enabling high-resolution solid-state NMR studies of large proteins with over 250 amino-acid residues, e.g. full-length prions, ${ }^{[20,21,31]}$ membrane proteins, ${ }^{[32]}$ and large protein complexes. ${ }^{[33,34]}$

Thanks to progress in sample preparation, the line width in many of the interesting systems mentioned above is the same or nearly the same as for the HET-s model system, ${ }^{[22,35-37]}$ and the increased sensitivity needed to perform higher-dimensional spectroscopy ${ }^{[38,39]}$ together with the improved dispersion in each of these dimensions should allow for the assignment of large systems (monomer size around 50 $\mathrm{kDa}$ ) as sediments fibrils, or membrane preparations. For instance, large proteins prepared by 'sedimentation' (i.e. centrifuged within the NMR MAS rotor by spinning the aqueous solution of the protein under MAS) provide solid-state NMR spectra of quality comparable with that of the best micro-crystalline samples. Fig. 4 shows the comparison of the solid-state NMR spectra of dodecameres formed by the helicase DnaB (monomer mass 59 $\mathrm{kDa}$ ) from a sedimented and a micro-crystalline sample. ${ }^{[12]}$ The line widths of both the samples are the same, typical of (locally) well-ordered systems.

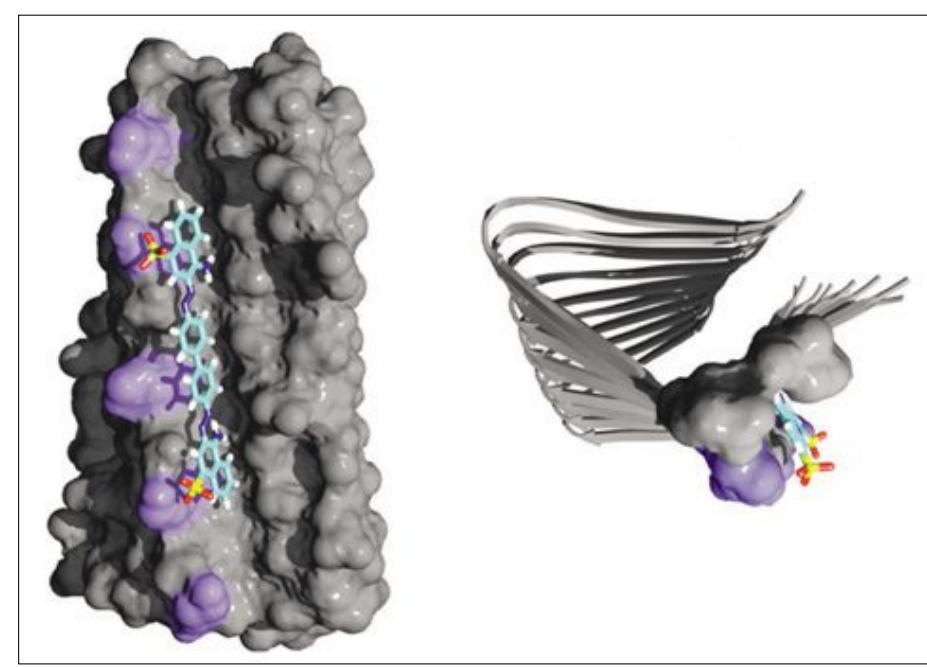

Fig. 2. Structure of Congo red docked to HET-s(218-289). Left: Side view of the complex. The key residue for binding, $\mathrm{K} 229$, is marked in purple. Right: Top view showing how Congo red enters the pronounced groove formed by K229/ E265 and S227/ S263 (shown in surface representation). Figure adapted from ref. [18].
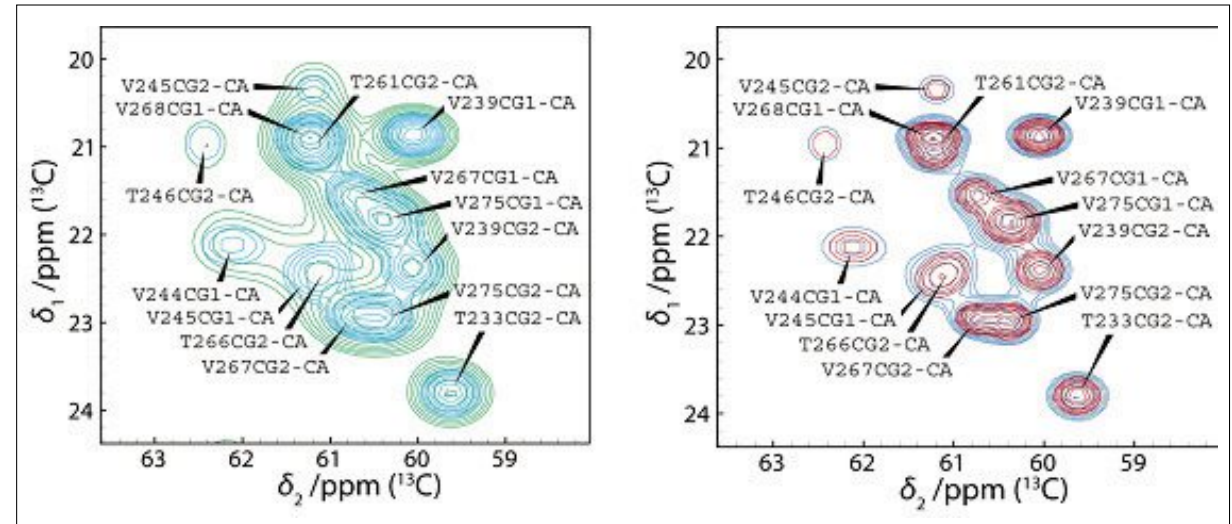

Fig. $3 .{ }^{13} \mathrm{C}-{ }^{13} \mathrm{C}$ correlation DARR spectra of HET-s(218-289). Cyan contours represent the spectrum simulated at $\mathrm{B}_{0}=20.0 \mathrm{~T}$ (corresponding to a proton resonance frequency of $850 \mathrm{MHz}$ ); the green contours are the simulated spectrum with the line widths calculated for $B_{0}=14.1 \mathrm{~T}$ (corresponding to a proton resonance frequency of $600 \mathrm{MHz}$ ) and the magenta contours for $\mathrm{B}_{0}=25.8$ $\mathrm{T}$ (corresponding to a proton resonance frequency of $1100 \mathrm{MHz}$ ). The frequencies and line widths are based on the experimental data measured at $\mathrm{B}_{0}=20.0 \mathrm{~T}$ and the predictions for $14.1 \mathrm{~T}$ correspond to the experimental linewidth.

Spectroscopy at higher fields will pose new challenges and provide new opportunities with respect to polarization transfer, recoupling and decoupling, and the NMR researchers at ETH are ready and excited to meet the challenges. Floquet-theory based operator theories will be one of the important tools to describe the complex spin dynamics which is influenced by several time dependences, including MAS sample rotation and radio-frequency fields (amplitudes and phases) on several channels $\left({ }^{1} \mathrm{H},{ }^{2} \mathrm{H},{ }^{15} \mathrm{~N},{ }^{13} \mathrm{C}\right) .{ }^{[40]}$ Parallel to the increase in magnetic fields, the obtainable MAS frequencies increase (with a worldrecord of $110 \mathrm{kHz}$ today) which also offers new challenges and possibilities. [10,38,41-47]

\section{Future developments}

Bruker BioSpin and ETH Zurich share a long and successful history in the development of Magnetic Resonance technology. This has led to a successful industrial endeavor for Bruker, growing from an idea

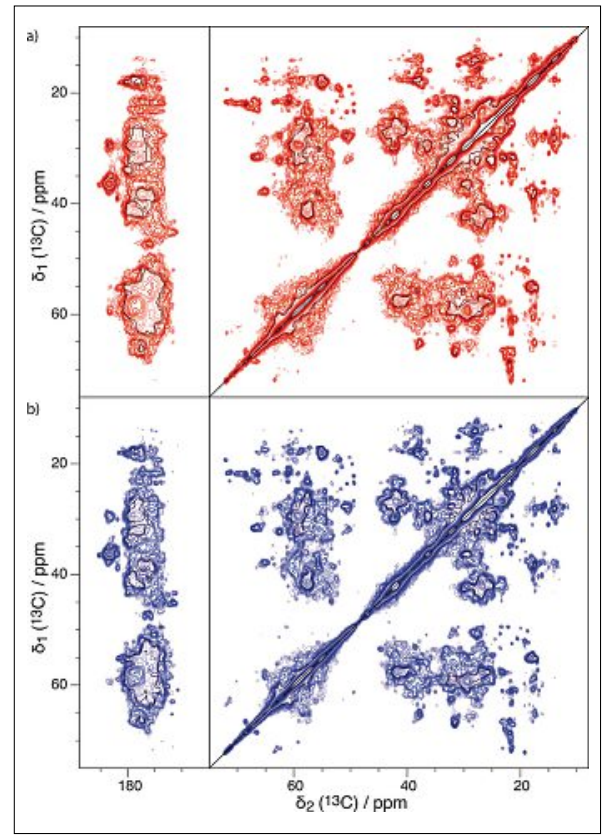

Fig. $4 .{ }^{13} \mathrm{C}-{ }^{13} \mathrm{C}$ correlation DARR spectra of the protein DnaB: a) sedimented (in red) and b) micro-crystalline (in blue) DnaB samples. Figure from ref. [12]. 
by its founder Prof. Günther Laukien into a international player in analytical instrumentation, in particular a worldwide market leader of Nuclear Magnetic Resonance (NMR) instrumentation. In parallel, at ETH the pioneering developments in magnetic resonance technologies, hardware and theory, resulted in the award of the Nobel Prizes for Chemistry to Prof. Richard Ernst (1991) and Prof. Kurt Wüthrich (2002). The longstanding relationship between Professor Ernst and Bruker, as well as the role of ETH Zurich in the development of magnetic resonance, has been described very eloquently in a 2010 article $^{[48]}$ entitled 'Zurich's Contributions to 50 Years Development of Bruker'.

Today, as much as in the past, progress in instrumentation and progress in applications of magnetic resonance are closely related. In both aspects, but of course primarily in instrumentation, Bruker Biospin has played a decisive role. To further strengthen the existing ties between Bruker and ETH, the idea of jointly establishing a magnetic resonance facility at ETH was born. It is our vision that such a facility is equipped with the latest, unique NMR instrumentation, and we are honored that Prof. Ernst has agreed to lend his name to this facility. In the initial phase, we have focused on solid-state NMR and the Richard R. Ernst Magnetic Resonance Facility is expected to soon have the probably world's first $1.1 \mathrm{GHz}$ wide-bore NMR spectrometer and will thrive on implementing techniques and applications at the highest available static magnetic field. Our aim is that the Richard R. Ernst Magnetic Resonance Facility will act well as a 'magnet' for national and international research collaborations.

\section{Acknowledgements}

We thank the ETH Zurich, the Swiss National Science Foundation and the European Commission for generous support over many years. The foundation of the Center would never have been possible without the effort of many generations of graduate students and postdocs at the Laboratory of Physical Chemistry and the pioneering efforts of Profs. Günthard, Primas and Ernst. Many of the results presented here were obtained in the context of longstanding collaborations with Matthias Ernst (ETH), Anja Böckmann (Lyon) and Roland Riek (ETH).
[1] F. Castellani, B. van Rossum, A. Diehl, M. Schubert, K. Rehbein, H. Oschkinat, Nature 2002, 420, 98 .

[2] A. Lange, S. Becker, K. Seidel, K. Giller, O. Pongs, M. Baldus, Angew. Chem. Int. Ed. 2005, 44, 2089.

[3] D. H. Zhou, J. J. Shea, A. J. Nieuwkoop, W. T. Franks, B. J. Wylie, C. Mullen, D. Sandoz, C. M. Rienstra, Angew. Chem. Int. Ed. 2007, 46, 8380.

[4] S. Balayssac, I. Bertini, A. Bhaumik, M. Lelli, C. Luchinat, Proc. Natl. Acad. Sci. USA 2008, 105, 17284.

[5] S. Zech, A. Wand, A. McDermott, J. Am. Chem. Soc. 2005, 127, 8618 .

[6] T. Manolikas, T. Herrmann, B. H. Meier, J. Am. Chem. Soc. 2008, 130, 3959.

[7] A. Loquet, B. Bardiaux, C. Gardiennet, C. Blanchet, M. Baldus, M. Nilges, T. Malliavin, A. Böckmann, J. Am. Chem. Soc. 2008, 130, 3579 .

[8] A. Böckmann, Angew. Chem. Int. Ed. 2008, 47, 6110.

[9] P. Schanda, M. Huber, J. Boisbouvier, B. H. Meier, M. Ernst, Angew. Chem. Int. Ed. 2011, 50, 11005 .

[10] P. Schanda, B. H. Meier, M. Ernst, J. Am. Chem. Soc. 2010, 132, 15957.

[11] I. Bertini, F. Engelke, C. Luchinat, G. Parigi, E. Ravera, C. Rosa, P. Turano, PhysChemChemPhys 2012, 14, 439.

[12] C. Gardiennet, A. K. Schütz, A. Hunkeler, B. Kunert, L. Terradot, A. Böckmann, B. H. Meier, Angew. Chem. Int. Ed. 2012, 51, 7855.

[13] A. Petkova, Y. Ishii, J. Balbach, O. Antzutkin, R. Leapman, F. Delaglio, R. Tycko, Proc. Natl. Acad. Sci. USA 2002, 262663499.

[14] C. Jaroniec, C. MacPhee, V. Bajaj, M. McMahon, C. Dobson, R. Griffin, Proc. Natl. Acad. Sci. USA 2004, 101, 711 .

[15] C. Wasmer, A. Lange, H. van Melckebeke, A. B. Siemer, R. Riek, B. H. Meier, Science 2008, 319, 1523.

[16] H. van Melckebeke, C. Wasmer, A. Lange, E. Ab, A. Loquet, A. Böckmann, B. H. Meier, J. Am. Chem. Soc. 2010, 132, 13765

[17] M. Sawaya, S. Sambashivan, R. Nelson, M. Ivanova, S. Sievers, M. Apostol, M. Thompson, M. Balbirnie, J. Wiltzius, H. McFarlane, A. Madsen, C. Riekel, D. Eisenberg, Nature 2007, $447,453$.

[18] A. K. Schutz, A. Soragni, S. Hornemann, A. Aguzzi, M. Ernst, A. Böckmann, B. H. Meier, Angew. Chem. Int. Ed. 2011, 50, 5956.

[19] D. Fowler, A. Koulov, W. Balch, J. Kelly, Trends Biochem. Sci. 2007, 32, 217.

[20] C. Wasmer, A. Schütz, A. Loquet, C. Buhtz, J. Greenwald, R. Riek, A. Böckmann, B. H. Meier, J. Mol. Biol. 2009, 394, 119.

[21] A. Loquet, L. Bousset, C. Gardiennet, Y. Sourigues, C. Wasmer, B. Habenstein, A. Schütz, B. H. Meier, R. Melki, A. Böckmann, J. Mol. Biol. 2009, 394, 108.

[22] J. Gath, B. Habenstein, L. Bousset, R. Melki, B. H. Meier, A. Böckmann, Biomol. NMR Assign. 2012, $6,51$.

[23] H. Heise, W. Hoyer, S. Becker, O. Andronesi, D. Riedel, M. Baldus, Proc. Natl. Acad. Sci. USA 2005, 102, 15871.

[24] H. van Melckebeke, P. Schanda, J. Gath, C. Wasmer, R. Verel, A. Lange, B. H. Meier, A. Böckmann, J. Mol. Biol. 2011, 405, 765.

[25] A. Lesage, C. Gardiennet, A. Loquet, R. Verel,
G. Pintacuda, L. Emsley, B. H. Meier, A. Böckmann, Angew. Chem. Int. Ed. 2008, 47, 5851.

[26] A. Lesage, A. Böckmann, J. Am. Chem. Soc. 2003, 125, 13336.

[27] C. Wasmer, A. Zimmer, R. Sabate, A. Soragni, S. J. Saupe, C. Ritter, B. H. Meier, J. Mol. Biol. 2010, 402, 311.

[28] C. Ritter, M. Maddelein, A. Siemer, T. Luhrs, M. Ernst, B. H. Meier, S. Saupe, R. Riek, Nature 2005, 435, 844.

[29] C. Wasmer, L. Benkemoun, R. Sabate, M. O. Steinmetz, B. Coulary-Salin, L. Wang, R. Riek, S. J. Saupe, B. H. Meier, Angew. Chem. Int. Ed. 2009, $48,4858$.

[30] C. Wasmer, A. Soragni, R. Sabaté, A. Lange, R. Riek, B. H. Meier, Angew. Chem. Int. Ed. 2008, 47, 5839.

[31] A. Böckmann, B. H. Meier, Prion 2010, 4, 72.

[32] S. D. Cady, K. Schmidt-Rohr, J. Wang, C. S. Soto, W. F. Degrado, M. Hong, Nature 2010, $463,689$.

[33] S. Jehle, M. Falb, J. P. Kirkpatrick, H. Oschkinat, B.-J. van Rossum, G. Althoff, T. Carlomagno, J. Am. Chem. Soc. 2010, 132, 3842.

[34] A. Mainz, S. Jehle, B. J. van Rossum, H. Oschkinat, B. Reif, J. Am. Chem. Soc. 2009, $131,15968$.

[35] B. Habenstein, C. Wasmer, L. Bousset, Y. Sourigues, A. Schütz, A. Loquet, B. H. Meier, R. Melki, A. Böckmann, J. Biomol. NMR 2011, 51, 235.

[36] B. Habenstein, L. Bousset, Y. Sourigues, M. Kabani, A. Loquet, B. H. Meier, R. Melki, A. Böckmann, Angew. Chem. Int. Ed., in press.

[37] A. Böckmann, C. Gardiennet, R. Verel, A. Hunkeler, A. Loquet, G. Pintacuda, L. Emsley, B. H. Meier, A. Lesage, J. Biomol. NMR 2009, 45,319 .

[38] M. Huber, S. Hiller, P. Schanda, M. Ernst, A. Böckmann, R. Verel, B. H. Meier, ChemPhysChem 2011, 12, 915.

[39] M. Huber, A. Böckmann, S. Hiller, B. H. Meier, PhysChemChemPhys 2012, 14, 5239.

[40] I. Scholz, B. H. Meier, M. Ernst, J. Chem. Phys. 2007, 127, 204504.

[41] M. Ernst, J. Magn. Reson. 2003, 162, 1.

[42] M. Ernst, M. A. Meier, T. Tuherm, A. Samoson, B. H. Meier, J. Am. Chem. Soc. 2004, 126, 4764.

[43] M. Ernst, A. Samoson, B. H. Meier, J. Magn. Reson. 2003, 163, 332.

[44] M. Ernst, A. Samoson, B. H. Meier, J. Chem. Phys. 2005, 123, 064102.

[45] M. Ernst, A. Detken, A. Böckmann, B. H. Meier, J. Am. Chem. Soc. 2003, 125, 15807.

[46] I. Scholz, B. H. Meier, M. Ernst, Chem. Phys. Lett. 2010, 485, 335.

[47] P. Schanda, M. Huber, R. Verel, M. Ernst, B. H. Meier, Angew. Chem. Int. Ed. 2009, 48, 9322.

[48] R. R. Ernst, Angew. Chem. Int. Ed. 2010, 49, 8310 . 